\title{
Climatic risks and impacts in South Asia: extremes of water scarcity and excess
}

Article

Accepted Version

Vinke, K., Martin, M. A., Adams, S., Baarsch, F., Bondeau, A., Coumou, D., Donner, R. V., Menon, A., Perette, M., Rehfeld, K., Robinson, A., Rocha, M., Schaeffer, M., Schwan, S., Serdeczny, O. and Svirejeva-Hopkins, A. (2017) Climatic risks and impacts in South Asia: extremes of water scarcity and excess. Regional Environmental Change, 17 (6). pp. 15691583. ISSN 1436-378X doi: https://doi.org/10.1007/s10113015-0924-9 Available at https://centaur.reading.ac.uk/62915/

It is advisable to refer to the publisher's version if you intend to cite from the work. See Guidance on citing.

Published version at: http://link.springer.com/article/10.1007/s10113-015-0924-9

To link to this article DOI: http://dx.doi.org/10.1007/s10113-015-0924-9

Publisher: Springer Verlag

All outputs in CentAUR are protected by Intellectual Property Rights law, including copyright law. Copyright and IPR is retained by the creators or other copyright holders. Terms and conditions for use of this material are defined in the End User Agreement. 


\section{CentAUR}

Central Archive at the University of Reading

Reading's research outputs online 


\title{
Climatic Risks and Impacts in South Asia: Extremes of Water Scarcity and Excess
}

\author{
Kira Vinkel, Maria A. Martin ${ }^{1}$, Sophie Adams ${ }^{2,4}$, Florent Baarsch, Alberte Bondeau, Dim \\ Coumou $^{1}$, Reik V. Donner ${ }^{1}$, Arathy Menon ${ }^{8}$, Mahé Perrette ${ }^{1}$, Kira Rehfeld ${ }^{5}$, Alexander Robinson ${ }^{1,6}$, \\ Marcia Rocha ${ }^{3}$, Michiel Schaeffer ${ }^{3}$, Susanne Schwan ${ }^{7}$, Olivia Serdeczny ${ }^{3}$, Anastasia Svirejeva- \\ Hopkins ${ }^{l}$
}

\section{Corresponding Author:}

Maria A. Martin, martin@pik-potsdam.de ; Tel: +49 33128820803 ; Fax: +49 3312882510

Author Emails: Kira Vinke: vinke@pik-potsdam.de, Maria A. Martin: martin@pik-potsdam.de, Sophie Adams: sophie.adams@climateanalytics.org, Florent Baarsch: florent.baarsch@climateanalytics.org, Alberte Bondeau: alberte.bondeau@imbe.fr, Dim Coumou: Coumou@pik-potsdam.de, Reik V. Donner: Reik.Donner@pikpotsdam.de, Arathy Menon: arathy.menon@ reading.ac.uk.de, Mahé Perrette: Mahe.perrette@ pik-potsdam.de, Kira Rehfeld: kira.rehfeld@awi.de, Alexander Robinson: robinson@ fis.ucm.es, Marcia Rocha: marcia.rocha@climateanalytics.org, Michiel Schaeffer: michiel.schaeffer@climateanalytics.org, Susanne Schwan: susanne.schwan@giz.de, Olivia Serdeczny: Olivia.Serdeczny@pik-potsdam.de, Anastasia Svirejeva-Hopkins: hopkins@pik-potsdam.de

\section{Acknowledgments:}

We thank all contributors to the World Bank Report "Turn Down the Heat: Climate Extremes, Regional Impacts and the Case for Resilience", which is the basis for this regional review.

RVD was financially supported by the German Federal Ministry for Education and Research (BMBF) via the Young Investigator's Group CoSy-CC ${ }^{2}$ (grant no. 01LN1306A).

For the calculation of warming levels referred to in figure 1 and online resource 1 , a special tool developed and programmed at PIK has been used: http://54.72.92.185/choices

Abstract: This paper reviews the current knowledge of climatic risks and impacts in South Asia associated with anthropogenic warming levels of $1.5^{\circ} \mathrm{C}$ to $4^{\circ} \mathrm{C}$ above pre-industrial values in the 21 st century. It is based on the World Bank Report "Turn Down the Heat, Climate Extremes, Regional Impacts and the Case for Resilience" (2013). Many of the climate change impacts in the region, which appear quite severe even with relatively modest warming of $1.5-2^{\circ} \mathrm{C}$, pose significant hazards to development. For example, increased monsoon variability and loss or glacial meltwater will likely confront populations with ongoing and multiple challenges. The result is a significant risk to stable and reliable water resources for the region, with increases in peak flows potentially causing floods and dry season flow reductions threatening agriculture. Irrespective of the anticipated economic development and growth, climate projections indicate that large parts of South Asia's growing population and especially the poor are likely to remain highly vulnerable to climate change.

Keywords: South Asia, Climate Change, Climate Impacts, Water, Agriculture

\footnotetext{
${ }^{1}$ Potsdam Institute for Climate Impact Research, Telegraphenberg A31, 14412 Potsdam, Germany

${ }^{2}$ University of New South Wales, High St, Kensington NSW 2052, Australia

${ }^{3}$ Climate Analytics, Friedrichstraße 231, 10969 Berlin, Germany

${ }^{4}$ Institut Méditerranéen de Biodiversité et d'Ecologie marine et continentale (IMBE)

Aix Marseille Université, CNRS, IRD, Avignon Université, Aix-en-Provence, France

${ }^{5}$ Alfred Wegener Institute for Polar and Marine Research, Telegraphenberg A43, 14412 Potsdam, Germany

${ }^{6}$ Universidad Complutense de Madrid, Ciudad Universitaria, 28040 Madrid, Spain

${ }^{7}$ Deutsche Gesellschaft für Internationale Zusammenarbeit, Dag-Hammarskjöld-Weg 1-5, 65760 Eschborn, Germany

${ }^{8}$ NCAS-Climate, University of Reading, Reading RG6 6BB, UK
} 
Word Count: 8551 plus one figure (counted as 300 words) $=8851$ words

\section{Introduction}

South Asia, here referring to a region comprising the seven countries Bangladesh, Bhutan, India, the Maldives, Nepal, Pakistan and Sri Lanka, has a total population of about 1.6 billion people as of 2010, projected to rise to over 2.2 billion by 2050 (World Bank 2013b). The region has seen robust economic growth in recent years, yet poverty remains widespread and projected changes in the climate could severely affect the rural economy and agriculture. Dense urban populations meanwhile are especially vulnerable to heat extremes, flooding, and disease.

This paper aims at providing a condensed overview of the scientific findings on the physical and biophysical impacts in South Asia based on the Turn Down the Heat Report (2013). Both the methodology and scope of this analysis reflect those of the report. The framing of this overview, however, diverges from the original form as can be seen from the structure outlined below. The evaluation of the presented findings thus also follows a different approach.

The first section (Climate) gives a concise, state of the art overview of the physical aspects of climate change, such as temperature or precipitation changes, to be expected in South Asia in a $2^{\circ} \mathrm{C}$ and a $4^{\circ} \mathrm{C}$ world, respectively. While current warming levels have already led to observable, non-negligible impacts, they are not the focus of this analysis. This paper rather aims at highlighting the difference between a $2^{\circ} \mathrm{C}$ and $4{ }^{\circ} \mathrm{C}$ world, in order to clarify the consequences of current choices in climate policy. The climate section will provide the basis for the analysis of climate change impacts on different sectors presented in the next section (Impacts). Here, the focus lies on the combined and multiple, interacting physical and biophysical impacts that climatic changes have on human systems, organized into two sections that are also intertwined: water and agriculture-related impacts. This is followed by an analysis of how these resulting impacts interact with human livelihoods. An overview of the results is given in tabular form in Online Resource 1, a short version thereof in Figure 1.

\section{Climate}

The results on temperature and precipitation in South Asia in this section are, if not referenced otherwise, based on our own analysis (compare Coumou and Robinson, 2013) of five bias-corrected CMIP5 models as in the ISIMIP effort (Warszawski et al. 2014). The terms " $2{ }^{\circ} \mathrm{C}$ world" and " $4{ }^{\circ} \mathrm{C}$ world" therein refer to the scenarios RCP2.6 and RCP 8.5 by the end of the century (which refers to the average of the time period 2071-2099, if not mentioned otherwise). The baseline period is 1951-80.

Our understanding of the physical aspects of climate change presented in this section is different for each type of climatic change: For example, in contrast to the processes behind temperature responses to increased greenhouse gas emissions, which are fairly well understood, projecting the hydrological cycle poses inherent difficulties because of the higher complexity of the physical processes and the scarcity of long-term, high-resolution rainfall observations (Allen and Ingram 2002). Precipitation projections hence have a much larger spread and uncertainty than temperature projections, both for strength and localization.

\section{Temperature}

A warming trend has begun to emerge over South Asia in the last few decades, particularly in India, and appears to be consistent with the signal expected from human-induced climate change (Kumar et al 2010). As for the $21^{\text {st }}$ century, a $2^{\circ} \mathrm{C}$ world shows substantially lower average warming over the South Asian land area than would occur in a $4^{\circ} \mathrm{C}$ world. In a $4^{\circ} \mathrm{C}$ world, South Asian summer temperatures are projected to increase by $3^{\circ} \mathrm{C}$ to nearly $6^{\circ} \mathrm{C}$ above the baseline by 2100 , with the warming most pronounced in Pakistan (see Figure OR1, in Online Resource 1). 
While that pattern is the same in a $2^{\circ} \mathrm{C}$ world, the warming by the end of the century is limited to $2^{\circ} \mathrm{C}$ in the North West and to $1{ }^{\circ} \mathrm{C}$ to $2^{\circ} \mathrm{C}$ in the remaining regions. In absolute terms, inland regions in India warm somewhat more than the coast. Relative to the local year-to-year natural variability - which is the relevant measure for adaptation capacity - the pattern is reversed, especially in the southwest. In a $4^{\circ} \mathrm{C}$ world, the west coast and southern India, as well as Bhutan and northern Bangladesh, even shift to new climatic regimes, with the monthly temperature distribution moving 5-6 standard deviations toward warmer values. These projections are consistent with other assessments based on CMIP3 models (see, e.g. Kumar et al., 2010).

\section{Heat Extremes}

The exposure to an increase in heat extremes could be substantially limited by holding warming below $2^{\circ} \mathrm{C}$ compared to the prospects of a $4^{\circ} \mathrm{C}$ world (Coumou and Robinson 2013). In a $4^{\circ} \mathrm{C}$ world, our model analysis for South Asia shows a strong increase in the frequency of boreal summer months hotter than 5-sigma (with respect to the historical mean) over the Indian subcontinent, especially in the south and along the coast as well as for Bhutan and parts of Nepal (Figure OR2, right bottom panel). By 2100, there is an approximately 60-percent chance that a summer month will be hotter than 5 -sigma in the multimodel mean, very close to the global average percentage. The limitation of surface area for averaging to South Asia, however, implies that there is larger uncertainty about the timing and magnitude of the increase in frequency of extremely hot months. Still, by the end of the $21^{\text {st }}$ century, most summer months in the north of the region ( $>50$ percent) and almost all summer months in the south $(>90$ percent) would be hotter than 3-sigma under RCP8.5 (Figure OR2, right top panel).

In a $2^{\circ} \mathrm{C}$ world, in contrast, most of the high-impact heat extremes projected by RCP8.5 for the end of the century would be avoided. Extremes beyond 5-sigma would be virtually absent, except for the southernmost tip of India and Sri Lanka (Figure OR2, bottom left panel). The less extreme months (i.e., beyond 3-sigma), however, would still increase substantially and cover about 20 percent of the surface area of the Indian subcontinent (Figure OR2, top left panel). The increase in frequency of these events would occur in the near term and level off by mid-century. Thus, irrespective of the future emission scenario, the frequency of extreme summer months beyond 3-sigma in the near term would increase several fold. By the second half of the $21^{\text {st }}$ century, mitigation would have a strong effect on the number and intensity of extremes.

For the Indian subcontinent, the multi-model mean of all CMIP5 models projects that warm spells, with consecutive days beyond the $90^{\text {th }}$ percentile, will lengthen to 150-200 days under RCP8.5, but only to 20-45 days under RCP2.6 (Sillmann et al. 2013).

\section{Precipitation}

A warmer atmosphere can carry significantly more water than a cooler one based on thermodynamic considerations. Taking into account energy balance considerations, climate models generally project an increase in global mean precipitation of about 2 percent per degree of warming.

In the 5 bias-corrected GCMs analyzed here, annual mean precipitation increases under both emissions of greenhouse gases and aerosols in the RCP2.6 and RCP8.5 scenarios over most areas of the region (Figure OR3, top row). The notable exception is western Pakistan. The percentage increase in precipitation is enhanced under RCP8.5, and the region stretching from the northwest coast to the southeast coast of the Indian peninsula will experience the highest percentage ( $\sim 30$ percent) increase in annual mean rainfall.

The percentage change in summer (JJA) precipitation (i.e., during the wet season) resembles that of the change in annual precipitation (Figure OR3, bottom row). The winter (DJF) precipitation (Figure OR3, middle row) shows a relative decrease in Pakistan and the central and northern regions of India, whereas the rest of the regions show inter-model uncertainty in the direction of change under the RCP8.5 scenario. This is in agreement with previous studies based on the IPCC AR4 (CMIP3) models (e.g., Chou et al., 2007), which suggest that the wet season gets wetter and the dry season gets drier. Under RCP2.6 the direction of the percentage change in winter rainfall shows large inter-model uncertainty over almost all regions of India. 
In addition to these patterns, there are observed increases in the frequency of the most extreme precipitation events (Gautam 2012; Gautam et al. 2009), with more extreme events occurring over the west coast and central and northeast India (Ajayamohan and Rao 2008; Goswami et al. 2006; Singh and Sontakke 2002). Also, the frequency of short drought periods increases (Deka et al. 2012). Deka et al. (2012) attribute this to a superposition of the effects of global warming on the normal monsoon system. They argue that these changes "indicate a greater degree of likelihood of heavy floods as well as short spell droughts. This is bound to pose major challenges to agriculture, water, and allied sectors in the near future."

\section{Monsoon}

Depending on the skill metric, most models are not able to resolve elementary aspects of the monsoon (onset, duration, break/active phases). However, model projections in general show an increase in the Indian monsoon rainfall under future emission scenarios of greenhouse gases and aerosols. The latest generation of models (CMIP5) confirms this picture, projecting an overall increase of approximately $2.3 \%$ per degree of warming for summer monsoon rainfall (Menon et al. 2013). The increase in precipitation simulated by the models is attributed to an increase in moisture availability in a warmer world. It is, somewhat paradoxically, found to be accompanied by a weakening of the monsoonal circulation (Bollasina, Ming, and Ramaswamy 2011; Krishnan et al. 2012; Turner and Annamalai 2012), which is explained by energy balance considerations (Allen and Ingram 2002). Compared to the pre-industrial period, selected CMIP5 models show an increase in mean monsoon rainfall of 5-20 percent in a $4{ }^{\circ} \mathrm{C}$ world (Jourdain et al. 2013). A significant uncertainty remains (see also hashed areas in Figure OR3), compare Collins et al. (2013) and Sperber et al. (2012).

Recent observations of total rainfall amounts during the monsoon period indicate a decline in the last few decades (Bollasina, Ming, and Ramaswamy 2011; Srivastava, Naresh Kumar, and Aggarwal 2010; Turner and Annamalai 2012; Wang et al. 2011). While the observed decline is inconsistent with the projected effects of global warming, there are indications that the decline could be (at least in part) due to the effects of black carbon and other anthropogenic aerosols (Bollasina, Ming, and Ramaswamy 2011; Turner and Annamalai 2012). Also, although most studies agree on the existence of this decrease, its magnitude and significance are highly dependent on the subregion on which the analysis is performed and the dataset that is chosen.

While most modeling studies project average annual mean increased monsoonal precipitation on decadal timescales, they also project significant increases in inter-annual and intra-seasonal variability (Endo et al. 2012; Kumar et al. 2010; May 2010; Menon, Levermann, and Schewe 2013; Sabade, Kulkarni, and Kripalani 2010; Turner and Annamalai 2012):

- An increase in the frequency of years with above-normal monsoon rainfall and of years with extremely deficient rainfall (Endo et al. 2012; Kripalani et al. 2007).

- An increase in the seasonality of rainfall, with more rainfall during the wet season (Fung, Lopez, and New 2011; Turner and Annamalai 2012), and an increase in the number of dry days (Gornall et al. 2010) and droughts (Dai, 2012; Kim and Byun 2009).

- An increase in the number of extreme precipitation events (Endo et al. 2012; Kumar et al. 2010). Changes in monsoon variability are expected to pose major challenges to human communities which depend on precipitation and river runoff as major sources of freshwater (see Water-Related Impacts). There are particularly large uncertainties in projections of spatial distribution and magnitude of the heaviest extremes of monsoon rainfall (Turner and Annamalai 2012). A potential abrupt change in the monsoon (Schewe and Levermann 2012) caused by global warming, toward a much dryer, lower rainfall state could cause major droughts which would likely precipitate a major crisis in South Asia. At this stage such a risk remains speculative - but clearly demands further research given the significant consequences of such an event. 


\section{Glacial Loss and River Flow}

Most of the Himalayan glaciers, where 80 percent of the moisture is supplied by the summer monsoon, have been retreating over the past century. The Indus and the Brahmaputra basins depend heavily on snow and glacial melt water, which make them extremely susceptible to climate-change-induced glacier melt and snowmelt (Immerzeel, van Beek, and Bierkens 2010). Very substantial reductions in the flow of the Indus and Brahmaputra in late spring and summer are projected for the coming few decades with a shift toward high winter and spring runoff likely well before a $2^{\circ} \mathrm{C}$ warming. These trends are projected to become quite extreme in a $4{ }^{\circ} \mathrm{C}$ warming scenario (Diffenbaugh, Scherer, and Ashfaq 2012). The Ganges, due to high annual downstream precipitation during the monsoon season, is less dependent on melt water (Immerzeel et al. 2010). The differences between the river basins are analyzed in some detail by Van Vliet et al. (2013).

Combined with precipitation changes, loss of glacial ice and a changing snowmelt regime could lead to substantial changes in downstream flow extremes. For example, the Brahmaputra may less frequently experience extreme low flow conditions in the future (Gain et al. 2011). However, there could be a strong increase in peak flow, which is associated with flood risks (Ghosh and Dutta 2012). Combined with projected sea-level rise, this could have serious implications for Bangladesh and other low-lying areas in the region (Gain et al. 2011).

\section{Sea-level Rise}

Current sea levels and projections of future sea-level rise are not uniform across the world and projections of local sea-level rise in South Asia show a stronger increase compared to higher latitudes (Perrette et al. 2013). Using a compilation of IPCC AR5 and other recent studies (see methods in World Bank 2014), regional sea-level rise in South Asia by the end of the $21^{\text {st }}$ century is projected to be approximately $0.65 \mathrm{~m}(0.4 \mathrm{~m}$ to $1.2 \mathrm{~m})$ in a $4^{\circ} \mathrm{C}$ and $0.4 \mathrm{~m}$ $(0.2 \mathrm{~m}$ to $0.7 \mathrm{~m})$ a $2^{\circ} \mathrm{C}$ world (relative to $\left.1986-2005\right)$. This is generally around 5-10 percent higher than the global mean. The projections of sea-level rise for a $2^{\circ} \mathrm{C}$ and a $4^{\circ} \mathrm{C}$ world (corresponding to RCP 2.6 and RCP 8.5 , respectively) start diverging significantly only in the second half of the $21^{\text {st }}$ century, each roughly 10 years ahead of the corresponding global mean development. The rate of sea-level rise, however, is an indicator with an even more pronounced difference between high- and low emission scenarios, with implications for adaptation processes and commitment to a larger divergence of sea-level rise between 2 and $4^{\circ} \mathrm{C}$ Worlds post 2100 . It features end-of-century rates of $13 \mathrm{~mm} / \mathrm{yr}$ ( 7 to $24 \mathrm{~mm} / \mathrm{yr}$ ) in a $4^{\circ} \mathrm{C}$ world, down to $4 \mathrm{~mm} / \mathrm{yr}$ ( 1 to $7 \mathrm{~mm} / \mathrm{yr}$ ) in a $2^{\circ} \mathrm{C}$ world. Note that the projections presented here include only the effects of human-induced global climate change and not those of local land subsidence due to natural or human influences; these factors need to be accounted for in projecting the local and regional risks, impacts, and consequences of sea-level rise.

\section{Tropical Cyclones}

For the northern Indian Ocean, recent changes in the total annual tropical cyclone (TC) frequency have not been significant (Knutson et al. 2010). However, the frequency of strong cyclones (SC) of category 4 and 5 has considerably increased over the last decades (1975-89: only 1 SC, 1990-2004: 7 SCs; cf. (Webster et al. 2005)). In parallel, the maximum wind speeds (within individual TCs) also displayed a significant upward trend (Elsner, Kossin, and Jagger 2008).

Most of the recent projections of future changes in the regional TC characteristics still suffer from an insufficient representation of TC generating mechanisms in state-of-the-art general circulation models (GCMs) (Emanuel, Sundararajan, and Williams 2008). As a consequence, there has been no full quantitative (and partly even no qualitative) consensus among different studies regarding expected changes in the (still generally low) annual TC frequency in the northern Indian Ocean (Murakami et al. 2012; Tory et al. 2013). However, some general tendencies have been identified recently:

- For a moderate $2^{\circ} \mathrm{C}$ warming scenario by 2100 , Gualdi et al. (2008) projected a systematic decrease of TC frequencies, while the average TC duration remains almost unchanged in comparison to present day. In 
turn, the cyclogenesis potential under the B1 emission scenario has been found to increase by $6 \%$ (Caron and Jones 2008).

- Under the $\mathrm{A} 1 \mathrm{~B}$ emission scenario (about $3.5^{\circ} \mathrm{C}$ warming in comparison to pre-industrial level by 2100 ), ensemble simulations with a high-resolution model have shown decreasing TC frequencies over the Bay of Bengal by 31\% until 2100, but a 46\% increase over the Arabian Sea (Murakami, Sugi, and Kitoh 2013). For the entire northern Indian Ocean (Emanuel, Sundararajan, and Williams 2008), this results in an overall increasing frequency. There is, however, a considerable uncertainty (J.-H. Kim, Brown, and McDonald 2011) related to the considerable spatial heterogeneity of trends as well as strong intra-annual variability (Murakami, Sugi, and Kitoh 2013; Murakami et al. 2012)

Regarding future TC intensities, Murakami et al. (2012) revealed a general upward tendency which is in accordance with a previously reported $10 \%$ increase in the cyclogenesis potential (Caron and Jones 2008).

- Under the even more severe A2 scenario, the possible number of TCs in the northern Indian Ocean would increase even further by about $16 \%$ in comparison to present day (Caron and Jones 2008), which is accompanied by a moderate increase in cyclogenesis potential (Chattopadhyay and Abbs 2012).

- Recent CMIP5 model results under RCP8.5 are in qualitative agreement with the aforementioned findings (Tory et al. 2013). 


\section{Impacts}

As climate change impacts are often closely intertwined with one another, a clear demarcation between them poses a methodological challenge. While many classifications may be valid, this paper deploys the following approach in order to provide an overview of the most important physical and biophysical impacts possibly affecting human life in South Asia: We provide a focus on physical and biophysical impacts on human systems, categorized into waterand agriculture-related impacts. Whereas these are closely interconnected (for instance, impacts on water influence agriculture, but agriculture also influences the atmospheric water cycle), they provide a working structure to form a representative description of the most significant impacts and their concomitant effects on livelihoods in South Asia. The complex interactions of impacts with livelihoods are divided into hunger and poverty, health, migration, and conflict. Naturally, these topics are also interlinked and there is a need to further connect the research, in order to fully assess aggregated risks from different sectors for the region.

\section{Water-Related Impacts}

Many of the climate risks and impacts that pose potential threats to populations in South Asia are associated with changes in the hydrological cycle - extreme rainfall, droughts, and declining snow fall and glacial loss in the Himalayas leading to changes in river flow. In the coastal regions those are combined with the consequences of sealevel rise and increased tropical cyclone intensity.

The climate of South Asia is dominated by the monsoon: The timely arrival of the summer monsoon, and its regularity, are critical for the rural regions and food production in South Asia.

The Indus, the Ganges, and the Brahmaputra basins provide water to approximately 750 million people (209 million, 478 million, and 62 million respectively in the year 2005; Immerzeel et al., 2010). In fact, a fifth of the world's population depends on the ecosystem of the Greater Himalaya region. An increasing occurrence of extremely low snow years and a shift toward extremely high winter/spring runoff and extremely low summer runoff would increase the flood risk during the winter/spring, and decrease the availability of freshwater during the summer (Giorgi et al. 2011).

\section{Floods}

The flooding events influenced or caused by climate change include glacial lake outbursts (Bates et al. 2008; Lal 2011; Mirza 2010), flash floods, inland river floods, extreme precipitation-causing landslides, and coastal river flooding, combined with the effects of sea-level rise and storm-surge-induced coastal flooding. Precipitation is the major cause of flooding (Mirza, 2010 and, for the example of the 2010 flash flood in Pakistan, Webster et al., 2011). Since 1980, the risks from flooding have grown mainly due to population and economic growth in coastal regions and low-lying areas. In South Asia, almost 45 million people were exposed to floods in 2010, accounting for approximately 65 percent of the global population exposed to floods in that year (UNISDR 2011).

The proportion of the population prone to river flooding increases rapidly with higher levels of warming (Arnell and Gosling 2013): Globally about twice as many people are predicted to be prone to flooding in 2100 in a $4^{\circ} \mathrm{C}$ world compared to a $2^{\circ} \mathrm{C}$ scenario and by the 2050s increases in the risk of flooding are particularly large for South Asia.

Deltaic regions in particular are vulnerable to more severe flooding, loss of wetlands, and a loss of infrastructure and livelihoods as a consequence of sea-level rise and climate-change-induced extreme events (Douglas 2009; Syvitski et al. 2009; World Bank 2010). Climate change is not the only driver of an increasing vulnerability to floods and sea-level rise. Human activities inland (such as upstream damming, irrigation barrages, and diversions) as well as activities on the delta (such as water withdrawal) can significantly affect the rate of aggradation and local subsidence in the delta. Subsurface mining is another driver (Syvitski et al. 2009).

Bangladesh is one of the most densely populated countries in the world, with a large population living within a few meters of sea level. Flooding of the Ganges-Brahmaputra-Meghna Delta occurs regularly and is part of the annual cycle of agriculture and life in the region. However, the fact that up to two-thirds of the land area of Bangladesh is flooded every three to five years already causes substantial damage to infrastructure, livelihoods, and agriculture- 
and especially to poor households (World Bank 2010). Projections consistently show substantial and growing risks for the country. Mirza (2010) estimates the flooded area could increase by as much as 29 percent for a $2.5^{\circ} \mathrm{C}$ increase in warming above pre-industrial levels. At higher levels of warming, the rate of increase in the extent of mean-flooded-area per degree of warming is estimated to be lower (Mirza 2010).

\section{Tropical Cyclones}

More intense tropical cyclones, combined with sea-level rise, would increase the depth and risk of inundation from floods and storm surges. Although only 15 percent of all tropical cyclones affect South Asia, India and Bangladesh alone account for 86 percent of global deaths from cyclones (UNISDR 2011). Furthermore, the highest risk of inundation is projected to occur in areas with the largest shares of poor people (Meams and Norton 2009). In Bangladesh, for example, a projected $27 \mathrm{~cm}$ sea-level rise by 2050, combined with a storm surge induced by an average 10-year, return-period cyclone such as Sidr (NASA, 2007; Wassmann et al., 2009b), could under certain conditions inundate an area 88-percent larger than the area inundated by current cyclonic storm surges (Meams and Norton 2009). Besides deaths and injuries, further indirect effects of floods and cyclones on health result from disruptions to food supply and access to safe drinking water.

\section{Droughts}

According to our own analysis, droughts are expected to pose an increasing risk in parts of the region, particularly Pakistan, while increasing wetness is projected for southern India (Figure OR3). The direction of change is uncertain for northern India. This is consistent with other estimates using projections in precipitation and warming (Dai 2012): for a global mean warming of $3^{\circ} \mathrm{C}$ by the end of the $21^{\text {st }}$ century, the drought risk expressed by the Palmer Drought Severity Index becomes higher across much of northwestern India, Pakistan (and also Afghanistan) but becomes lower across southern and eastern India. It should be noted that such projections are uncertain, not only due to the spread in model projections but also to the choice of drought indicator (Taylor et al. 2012).

The projected increase in seasonality of precipitation is associated with an increase in the number of dry days and droughts with adverse consequences for human lives.

\section{Water Security}

Future water security under climate change is a growing concern. It is dependent on the complex relationship among population growth, increases in agricultural and economic activity, increases in total precipitation, and the ultimate loss of glacial fed water and snow cover, combined with regional variations and changes in seasonality across South Asia. The assessment of water security threats is undertaken using differing metrics across the studies, making a comprehensive assessment difficult. Several studies find that South Asia is already a highly water-stressed region (Fung, Lopez, and New 2011; Vörösmarty et al. 2010). It has very low levels of water storage capacity per capita, which increases vulnerability to fluctuations in water flows and changing monsoon patterns (Ministry of Environment and Forests 2012).

Projections show that in most cases climate change aggravates the situation (De Fraiture and Wichelns 2010; ESCAP 2011; Green et al. 2011), particularly for the agricultural sector (Sadoff and Muller 2009), compare section Impacts on Agriculture. An example of the complexity of such prognoses can be seen in the work of Fung et al. (2011), who project the effects of global warming on river runoff in the Ganges basin. A warming of about $2.7^{\circ} \mathrm{C}$ above pre-industrial levels is projected to lead to a 20-percent increase in runoff, and a $4.7^{\circ} \mathrm{C}$ warming to approximately a 50-percent increase. While an increase in annual runoff sounds promising for a region in which many areas suffer from water scarcity (Bates et al. 2008; Döll 2009; ESCAP 2011), it has to be taken into account that the changes are unevenly distributed across wet and dry seasons. In projections by Fung et al. (2011), annual runoff increases in the wet season while further decreasing in the dry season - with the amplification increasing at higher levels of warming. This increase in seasonality implies severe flooding in high-flow seasons and aggravated water stress in dry months in the absence of large-scale infrastructure construction (Fung et al. 2011; World Bank 2012). 
For global warming of approximately $3{ }^{\circ} \mathrm{C}$ above pre-industrial levels and the SRES A2 population scenario for 2080, Gerten et al. (2011) project that it is very likely (>90 percent confidence) that per capita water availability in South Asia (except for Sri Lanka) will decrease by more than 10 percent. While the population level plays an important role in these estimates, there is a 10-30 percent likelihood that climate change alone is expected to decrease water availability by more than 10 percent in Pakistan. The likelihood of water scarcity driven by climate change alone is as high as $>90$ percent for Pakistan and Nepal and as high as 30-50 percent for India.

In a scenario of $2^{\circ} \mathrm{C}$ warming by 2050 , Rockström et al. (2009) project that food and water requirements in India would exceed the availability of green water (rainwater stored in the soil as soil moisture) by more than 150 percent, indicating that the country will be highly dependent on blue water (water from rivers and aquifers) for agricultural production. As early as 2050, water availability in Pakistan and Nepal is projected to be too low for self-sufficiency in food production when taking into account a total availability of water below $1300 \mathrm{~m}^{3}$ per capita per year as a benchmark for the amount of water required for a balanced diet (Rockström et al. 2009).

\section{Impacts on Agriculture}

Agriculture contributes approximately 18 percent to South Asia's GDP (2011 data based on World Bank, 2013a); more than 50 percent of the population is employed in the sector (2010 data based on World Bank, 2013a) and directly dependent on it. Productivity growth in agriculture is an important driver of poverty reduction. In spite of the paramount importance of this sector, even explaining the observed yields in South Asia remains a non-trivial task (Auffhammer, Ramanathan, and Vincent 2006, 2011; Kalra et al. 2008; Lin and Huybers 2012; Lobell et al. 2012; Pathak et al. 2003). Projecting agricultural output for the future is even more challenging: it could be expected that future improvements may occur due to technological changes, cultivar breeding and optimization, production efficiencies, and improved farm management practices. However, declining soil productivity, groundwater depletion (Green et al. 2011), and declining water availability, as well as increased pest incidence and salinity, already threaten sustainability and food security in South Asia (Wassmann, Jagadish, and Sumfleth 2009). The effects of climate change have the potential to further significantly aggravate the situation; however, due to the complexity of the issue, projections remain difficult.

\section{Extreme Heat Effects}

Heat stress, which can be particularly damaging during some development stages and may occur more frequently with climate change, is not yet widely included in crop models and projections.

Compared to calculations of potential yields without historic trends of temperature changes since the 1980s, rice and wheat yields have declined by approximately 8 percent for every $1{ }^{\circ} \mathrm{C}$ increase in average growing-season temperatures (Lobell, Schlenker, and Costa-Roberts 2011). If temperatures increase beyond the upper temperature for crop development (e.g., $25-31^{\circ} \mathrm{C}$ for rice and $20-25^{\circ} \mathrm{C}$ for wheat, depending on genotype), rapid decreases in the growth and productivity of crop yields could be expected, with greater temperature increases leading to greater production losses (Wassmann, Jagadish, and Sumfleth 2009). By introducing the response to heat stress within different crop models, Challinor, Wheeler, Garforth, Craufurd, and Kassam (2007) simulate significant yield decreases for rice (up to -21 percent under double $\mathrm{CO}_{2}$ ) and groundnut (up to -50 percent).

\section{Water Constraints}

Agricultural productivity is highly dependent on the hydrological cycle and freshwater availability (Jacoby, Mariano, and Skoufias 2011). In turn, agriculture and the food demands of a growing population are expected to be the major drivers of water usage in the future (De Fraiture and Wichelns 2010; Douglas 2009). At present, agriculture accounts for more than 91 percent of the total freshwater withdrawal in South Asia (including Afghanistan). Nepal (98 percent), Pakistan (94 percent), Bhutan (94 percent) and India (90 percent) have particularly high levels of water withdrawal through the agricultural sector (2011 data, by World Bank, 2013a). 
Immerzeel, van Beek, and Bierkens (2010) demonstrate how changes in water availability in the Indus, Ganges, and Brahmaputra rivers may impact food security. The authors estimate that with a temperature increase of $2-2.5^{\circ} \mathrm{C}$ compared to pre-industrial levels, by the 2050s reduced water availability for agricultural production may result in more than 63 million people no longer being able to meet their caloric demand by production in the river basins. Recent statistical analysis by Auffhammer, Ramanathan, and Vincent (2011) also confirm that changes in monsoon rainfall over India, with less frequent but more intense rainfall in the recent past (1966-2002) contributed to reduced rice yields. This decrease in production is due to both direct drought impacts on yields and to the reduction of the planted areas for some water-demanding crops (e.g., rice) as farmers observe that the monsoon may arrive too late (Gadgil and Rupa Kumar 2006). South Asia, and especially India and Pakistan, are highly sensitive to decreases in groundwater recharge - a situation that is expected to become more critical with climate change (Döll 2009; Green et al. 2011).

The changing variability of the monsoon season poses a severe risk to agriculture because farming systems in South Asia are highly adapted to the local climate, particularly the monsoon. Observations indicate the agricultural sector's vulnerability to changes in monsoon precipitation: with a 19-percent decline in summer monsoon rainfall in 2002, Indian food grain production was reduced by 10-15 percent compared to the previous decadal average (Mall et al. 2006). Without adequate water storage facilities, the potential increase of peak monsoon river flow would not be usable for agricultural productivity; increased peak flow may also cause damage to farmland due to river flooding (Gornall et al. 2010). Observations of agricultural production during ENSO (El Niño - Southern Oscillation) events confirm strong responses to variations in the monsoon regime. ENSO events play a key role in determining agricultural production (Iglesias, Erda, and Rosenzweig 1996). Several studies, using historical data on agricultural statistics and climate indices, have established significant correlations between summer monsoon rainfall anomalies, strongly driven by the ENSO events, and crop production anomalies (e.g.,Webster et al., 1998).

\section{Drought}

The droughts of 1987 and 2002-2003 affected more than 50 percent of the crop area in India (Wassmann, Jagadish, and Sumfleth 2009); in 2002, food grain production declined by 29 million tons compared to the previous year (UNISDR 2011). Local droughts in rainfed agricultural areas in northwest Bangladesh cause yield losses higher than those from flooding and submergence (Wassmann, Jagadish, and Sumfleth 2009)

\section{Salinization}

Soil salinity has been hypothesized to be one possible reason for observed yield stagnations and decreases in the Indo-Gangetic Plain (Ladha et al. 2003). Deltaic regions and wetlands are exposed to the risks of sea-level rise and increased inundation causing salinity intrusion into irrigation systems and groundwater resources. Also, higher temperatures would lead to excessive deposits of salt on the surface, further increasing the percentage of brackish groundwater (Wassmann, Jagadish, and Heuer 2009). However, similar to diminished groundwater availability, which is largely due to rates of extraction exceeding rates of recharge and is, in this sense, human induced (Bates et al. 2008) groundwater and soil salinization are also caused by the excessive use of groundwater in irrigated agriculture. Salinity stress through brackish groundwater and salt-affected soils reduces crop yields; climate change is expected to aggravate the situation (Wassmann, Jagadish, and Heuer 2009).

\section{Flooding, Sea-level Rise and Tropical Cyclones}

Flooding poses a particular risk to deltaic agricultural production. Even today, food shortages are a persistent problem in Bangladesh (Douglas 2009; Wassmann, Jagadish, and Sumfleth 2009). In this region, large amounts of productive land could be lost to sea-level rise, with 40-percent area losses projected in southern Bangladesh for a 65 $\mathrm{cm}$ rise by the 2080s (Yu et al. 2010). Tropical cyclones already lead to substantial damage to agricultural production, particularly in the Bay of Bengal region, yet very few assessments of the effects of climate change on agriculture in the region include estimates of the likely effects of increased tropical cyclone intensity. 


\section{Uncertain CO2 Fertilization Effect}

Despite the different representations of some specific biophysical processes, simulations generally show that the positive fertilization effect of the increasing atmospheric $\mathrm{CO}_{2}$ concentration may counteract the negative impacts of increased temperature (e.g., Challinor \& Wheeler 2008). Uncertainties associated with the representation or parameterization of the $\mathrm{CO}_{2}$ fertilization effect, however, lead to a large range of results given by different crop models. For example, large parts of South Asia are projected to experience significant declines in crop yield without $\mathrm{CO}_{2}$ fertilization, while increases are projected when taking the potential $\mathrm{CO}_{2}$ fertilization effect into account (Müller et al. 2010). However, controversy remains as to the strength of the effect, and there is considerable doubt that the full benefits can be obtained (Müller et al. 2010).

\section{Projected Changes in Food Production}

Nelson et al. (2010) estimate the direct effects of climate change (changes in temperature and precipitation for rainfed crops and temperature increases for irrigated crops) on the production of different crops with and without the effect of $\mathrm{CO}_{2}$ fertilization under a global mean warming of about $1.8^{\circ} \mathrm{C}$ above pre-industrial levels by 2050 . They find that South Asia is affected particularly hard by climate change - especially when the potential benefits of the $\mathrm{CO}_{2}$ fertilization effect are not included. If temperatures increase beyond the upper temperature for crop development (e.g., $25-31^{\circ} \mathrm{C}$ for rice and $20-25^{\circ} \mathrm{C}$ for wheat, depending on genotype), rapid decreases in the growth and productivity of crop yields could be expected, with greater temperature increases leading to greater production losses (Wassmann, Jagadish, and Sumfleth 2009). By analyzing the heat stress in Asian rice production for the period 1950-2000, Wassmann, Jagadish, and Heuer (2009) show that large areas in South Asia already exceed maximum average daytime temperatures of $33^{\circ} \mathrm{C}$. Auffhammer et al. (2006), in agreement with e.g. Pathak et al. (2003) and Kalra et al. (2008)show increasing minimum temperatures caused more than half of the total observed yield decline over the past decade and before. Present crop models may underestimate by as much as 50 percent the yield loss from local warming of $2^{\circ} \mathrm{C}$ (Lobell et al. 2012).

Without climate change, overall crop production is projected to increase significantly (by about 60 percent by 2050) although, per capita, crop production will likely not quite keep pace with projected population growth. Under climate change, however, a significant (about one-third) decline in per capita South Asian crop production is projected, if the $\mathrm{CO}_{2}$ fertilization effect does not persist and increase above present levels. The per capita calorie is projected to decline under climate change, while it will rise in the scenario without climate change. The same analysis expects the proportion of malnourished children to be substantially reduced by the 2050s without climate change. However, climate change is likely to partly offset this reduction, as the number of malnourished children is expected to increase by 7 million compared to the case without climate change (Nelson et al. 2010).

A meta-analysis of the impact of temperature increase on crop yields in the South Asia region from 9 different studies is presented in Online Resource 2 (originally prepared for the World Bank Report, 2013b).

\section{Impacts in Bangladesh}

While the risks for South Asia as a whole emerge as quite serious, the risks and impacts for Bangladesh are arguably amongst the highest in the region. Yu et al. (2010) conducted a comprehensive assessment of future crop performance and consequences of production losses for Bangladesh. Taking into account the impact of changes in temperature and precipitation, the uncertain benefits of $\mathrm{CO}_{2}$ fertilization, mean changes in floods and inundation, and rising sea levels, the authors estimate that climate change will cause a reduction of about 2-6.5 percent in annual rice production from 2005-50, depending on the scenario (World Bank 2010; Yu et al. 2010).

\section{Interactions of Physical and Biophysical Impacts with Livelihoods}

The human impacts of climate change will be determined by the socioeconomic context in which they occur. The following sections outline some of these expected implications, drawing attention to how particular groups in 
society, such as the poor, are most vulnerable to the threats posed by climate change. Climate-change impacts are projected to have immediate as well as long term consequences for livelihoods, especially for the poorest households, as well as for poverty reduction policies and efforts (Hallegatte et al. 2014).

\section{Hunger and Poverty}

Per capita calorie availability and child malnutrition - which are determinants for long-term growth and health - may be severely affected by climate change and its effect on the agricultural sector (Nelson et al. 2010). Furthermore, the uneven distribution of the impacts of climate change is expected to have adverse effects on poverty reduction. Hertel et al. (2010) show that, by 2030, rising food prices in response to productivity shocks would have the strongest adverse effects on a selected number of social strata. In a low-productivity scenario, described as a world with rapid temperature increases and crops highly sensitive to warming, higher earnings result in declining poverty rates for self-employed agricultural households. This is due to price increases following production shocks. Non-agricultural urban households, in turn, are expected to be most affected by food price increases. As a result, the poverty rate among this subpopulation rises by up to a third in Bangladesh in this scenario. Other means by which climate change can affect poor households, beyond the consequences of increasing food prices and decreased calorie availability still need to be investigated (Hallegatte et al. 2014). These channels could for example include the effects on assets and physical capital (e.g. a tropical cyclone destroying living premises), the effects on productivity (e.g. high temperature reducing labor productivity) and opportunities (e.g. the overall effect of climate variability and change on economic growth) (Hallegatte et al. 2014).

Health

Childhood Stunting: The negative effects of climate change on food production may have direct implications for malnutrition and undernutrition - increasing the risk of both poor health and rising death rates (Lloyd, Kovats, and Chalabi 2011). At present, more than 31 percent of children under the age of five in South Asia are underweight (2011 data based on World Bank 2013a). Using estimates of changes in calorie availability attributable to climate change, and particularly to its impact on crop production, Lloyd et al. (2011) estimate that climate change may lead to a 62-percent increase in severe childhood stunting and a 29-percent increase in moderate stunting in South Asia by 2050 for a warming of approximately $2^{\circ} \mathrm{C}$ above pre-industrial levels. As the model is based on the assumption that within-country food distribution remains at baseline levels, it would appear that better distribution could to some extent mitigate the projected increase in childhood stunting.

Diarrheal and Vector Borne Diseases: Diarrhea is at present a major cause for child mortality in Asia and the Pacific, with 13.1 percent of all deaths under age five in the region caused by diarrhoea (2008 data from ESCAP 2011). Pandey (2010) investigates the impact of climate change on the incidence of diarrheal disease in South Asia and finds a declining trend between 2010 and 2050. However, the author estimates a climate-change induced increase of 6.2 percent by 2030, and an increase of 1.1 percent by 2050, which is lower than the 2010 increase of 4.1 percent in the relative risk of disease from the baseline. Across the world, climate change induced incidence risk increases at an average of 3 percent in 2030 and 2 percent in 2050 (Pandey 2010). Noteworthy in this context is the finding by Pandey (2010) that, in the absence of climate change, cases of diarrheal disease in South Asia (including Afghanistan) would decrease earlier, as the expected increase in income would allow South Asian countries to invest in their health services.

Climate change is expected to affect the distribution of malaria in the region, causing it to spread into areas at the margins of the current distribution where colder climates had previously limited transmission of the vector-borne disease (Ebi et al. 2007). Pandey (2010) finds that the relative risk of malaria in South Asia is projected to increase by 5 percent in 2030 (174,000 additional incidents) and 4.3 percent in 2050 (116,000 additional incidents) in the model with higher precipitation (NCAR). The drier scenario (CSIRO) does not project an increase in risk; this may be because calculations of the relative risk of malaria consider the geographical distribution and not the extended duration of the malarial transmission season (Pandey 2010). As in the case of diarrheal disease, malaria cases are 
projected to significantly decrease in the absence of climate change from 4 million cases in 2030 to 3 million cases in 2050 (Pandey 2010). In a global study on the distribution of malaria Béguin et al., (2011) find that GDP growth per capita would have a stronger influence on the distribution of the disease than climate change, although the effects of climate change are still significant. Salinity intrusion into freshwater resources constitutes another health risk. About 20 million people in the coastal areas of Bangladesh are already exposed to salinity in their drinking water (Khan, Ireson, et al. 2011; Khan, Xun, et al. 2011). With rising sea levels and more intense cyclones and storm surges, the contamination of groundwater and surface water is expected to intensify. Contamination of drinking water by saltwater intrusion may cause an increasing number of cases of diarrhea (Khan, Ireson, et al. 2011; Khan, Xun, et al. 2011). Cholera outbreaks may also become more frequent as the bacterium that causes cholera, vibrio cholerae, survives longer in saline water (Khan, Ireson, et al. 2011; Khan, Xun, et al. 2011).

Heat Stress and Heat-Related Mortality: In South Asia, unusually high temperatures pose severe threats to health. Heat exhaustion can cause heatstroke and, in severe cases, death. In Andhra Pradesh, India, for example, heat waves caused 3,000 deaths in 2003 (Ministry of Environment and Forests 2012). In recent years, the death toll as a consequence of heat waves has increased continuously in the Indian states of Rajasthan, Gujarat, Bihar, and Punjab (Lal 2011). In their global review, Hajat and Kosatky (2010) find that increasing population density, lower city gross domestic product, and an increasing proportion of people aged 65 or older were all independently linked to increased rates of heat-related mortality. Moreover, air pollution, which is a considerable problem in South Asia, interacts with high temperatures and heat waves to increase fatalities. A study by Takahashi, Honda, and Emori (2007) further found that most South Asian countries are likely to experience a very substantial increase in excess mortality due to heat stress by the end of the $21^{\text {st }}$ century, based on a global mean warming for the 2090s of about $3.3^{\circ} \mathrm{C}$ above pre-industrial levels under the SRES A1B scenario and an estimated increase in the daily maximum temperature change over South Asia in the range of $2-3^{\circ} \mathrm{C}$. Takahashi, Honda, and Emori (2007) assume constant population densities. (Sillmann et al. 2013) projects, based on the CMIP5 models, an annual average maximum daily temperature increase in the summer months of approximately $4-6^{\circ} \mathrm{C}$ by 2100 for the RCP 8.5 scenario.

\section{Migration}

The potential for migration, including permanent relocation as well as short-term or seasonal migration, is expected to be heightened by climate change, particularly due to sea-level rise and erosion. There is a lack of consensus on the estimates of future migration patterns resulting from climate-change-related risks (Gemenne 2011; Bierbaum et al. 2009). Inland migration of households has already been observed in Bangladesh, where exposed coastal areas are characterized by lower population growth rates than the rest of the country (World Bank 2010). A sea-level rise of one meter is expected to affect 13 million people in Bangladesh (Huq, Ali, and Rahman 1995; World Bank 2010). However, this would not necessarily mean that all people affected would be permanently displaced (Gemenne 2011). Impacts on agriculture may cause impoverishment of rural populations, which in turn could either be more likely to migrate in order to diversify their income, or more likely to stay if resources for resettlement are depleted. Brecht et al. (2012) estimate that in a $4^{\circ} \mathrm{C}$ world, a possible sea-level rise of more than one meter could lead to storm surges with a $15 \%$ wave height increase, putting $20.1 \%$ of India's population under risk of exposure. Hugo (2011) identifies South Asia as a hotspot for both population growth and future international migration as a consequence of demographic changes, poverty, and the impacts of climate change. As migration is a multicausal phenomenon, the propensity for large-scale displacement depends on a variety of factors and the way they will interact. These include future regional trends of population growth and economic development in rural areas, as well as the severity of impacts and the scale of adaptive measures. More transdisciplinary research on these complex interactions is needed.

\section{Conflict}

Although there is likewise a lack of consensus on the causal connection between climate change and violent conflicts, there is evidence that impacts like water and food scarcity may increase the likelihood of conflict (De Stefano et al. 2012; Gautam 2012). A reduction in water availability from rivers, could cause conflict over access to this critical resource and thereby further threaten the water security of South Asia (Gautam 2012). In the context of 
declining quality and quantity of water supplies in the Indus and Ganges-Brahmaputra-Meghna Basins, the increasing demand for water is already causing tensions over water sharing (De Stefano et al. 2012; Uprety and Salman 2011). Uprety and Salman (2011) indicate that sharing and managing water resources in South Asia have become more complex due to the high vulnerability of the region to climate change. Based on the projections for water and food security presented above, it is likely that the risk of conflict over water resources may increase with the severity of the impacts. The estimated reduced per capita availability of water of $10 \%$ in a $3^{\circ} \mathrm{C}$ scenario by 2080 (Gerten et al. 2011) could mean that reductions for low-income households may be significantly higher than $10 \%$, whereas more economically resilient communities could pay higher prices for additional water supply and thereby sustain their water usage.

\section{Conclusion and Implications for Development}

Global climate change will manifest itself in various ways in the South Asian region, among them heat extremes, monsoon variability, river flow and tropical cyclones and sea-level rise. The projected impacts are considerable in a $2^{\circ} \mathrm{C}$ World and significantly higher in a $4{ }^{\circ} \mathrm{C}$ world, pointing to the need to avoid the latter in particular (World Bank 2012).

Many of the climate change impacts in the region, which appear quite severe even with relatively modest warming of $1.5-2^{\circ} \mathrm{C}$, pose significant challenges to development. The majority of the climatic risk factors are ultimately related to changes in the hydrological regime; these would affect populations via changes to precipitation patterns and river flow. One of the most immediate areas of impact resulting from changes in the hydrological regime is agriculture, which is highly dependent on the regularity of monsoonal rainfall. However, agriculture in the region is also sensitive to temperature increases of which projections can be made with higher levels of confidence than projections of changes in precipitation and hydrology. Should the trend of negative effects on crop yields persist, substantial yield reductions can be expected in the near and midterm.

The poor in South Asia are particularly vulnerable to the impacts of climate change. Disruptions in agriculture would undermine livelihoods and cause food price shocks. The risks to health associated with inadequate nutrition or unsafe drinking water are significant: childhood stunting, transmission of water-borne diseases and disorders associated with excess salinity. Other health threats are associated with flooding, heat waves, or tropical cyclones. Population displacement is likely to increase in case of more frequent and severe flooding and may also be a coping strategy for other impacts on livelihoods.

Bangladesh emerges as an impact hotspot with increasing and compounding challenges occurring in the same timeframe from extreme river floods, more intense tropical cyclones, rising sea levels, extraordinarily high temperatures, and declining crop yields. Increased river flooding combined with tropical cyclone surges pose a high risk of inundation in areas with the largest shares of poor populations. Moreover, coastal agglomerations such as the megacities Kolkata and Mumbai on the shores of South Asia are highly vulnerable to potentially cascading risks resulting from a combination of climatic changes such as sea-level rise, increased temperatures, increasingly intense tropical cyclones, and riverine flooding. Major adaptation measures would be needed to cope with the projected impacts of climate change. 


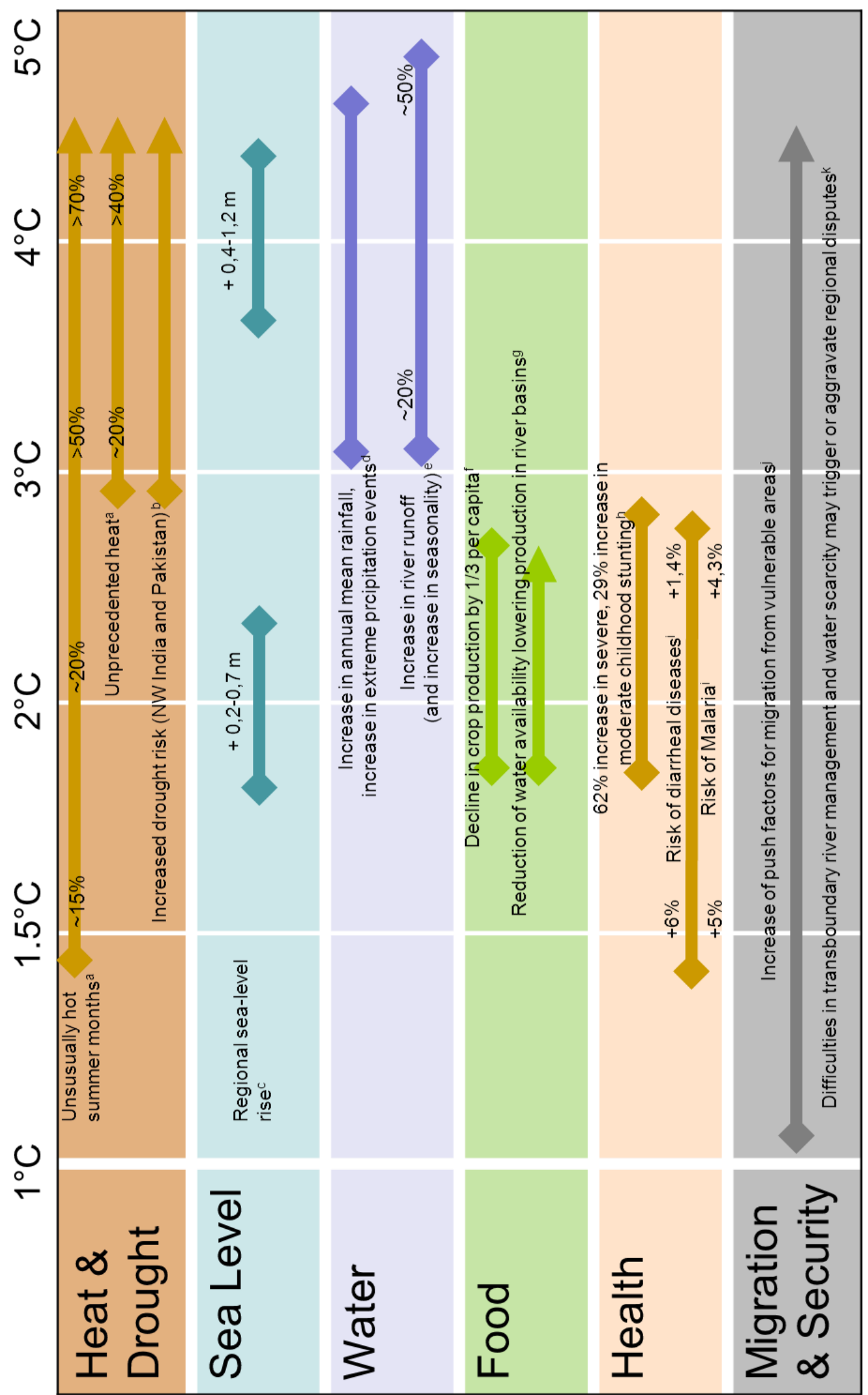




\section{Figure 1:}

Warming levels are relative to pre-industrial temperatures. The impacts shown here are a subset of those summarized in Table A of Online Resource 1. The arrows indicate the range of warming levels assessed in the underlying studies; but do not imply any graduation of risk unless noted explicitly. In addition, observed impacts or impacts occurring at lower or higher levels of warming that are not covered by the key studies highlighted here are not presented. Adaptation measures are not assessed here, but they can be crucial to alleviating the impacts of climate change. The layout of the figure is adapted from (Parry 2010). The superscript letters indicate the relevant references for each impact. If there is no letter, the results are based on additional analyses for this review.

\section{References:}

(a) (Coumou and Robinson 2013; World Bank 2013b); (b) (Dai 2012; D.-W. Kim and Byun 2009); (c) (World Bank 2013b); (d) (Coumou and Robinson 2013; Endo et al. 2012; Jourdain et al. 2013; Kumar et al. 2010); (e) (Fung, Lopez, and New 2011) ; (f) (Nelson et al. 2010 ; World Bank 2013b); (g) (Immerzeel et al. 2010; Rockström et al. 2009); (h) (Lloyd, Kovats, and Chalabi 2011); (i) (Pandey 2010) ; (j) (Hugo 2011; Huq, Ali, and Rahman 1995; World Bank 2010); (k) (P. K. Gautam 2012; De Stefano et al. 2012; Uprety and Salman 2011). 
Reference List

Ajayamohan RS, Rao SA (2008) Indian Ocean Dipole Modulates the Number of Extreme Rainfall Events over India in a Warming Environment. J Meteorol Soc Japan. doi: 10.2151/jmsj.86.245

Allen MR, Ingram WJ (2002) Constraints on future changes in climate and the hydrologic cycle. Nature 419:22432. doi: $10.1038 /$ nature 01092

Arnell NW, Gosling SN (2013) The impacts of climate change on river flow regimes at the global scale. J Hydrol 486:351-364. doi: http://dx.doi.org/10.1016/j.jhydrol.2013.02.010

Auffhammer M, Ramanathan V, Vincent JR (2006) Integrated model shows that atmospheric brown clouds and greenhouse gases have reduced rice harvests in India. Proc Natl Acad Sci U S A 103:19668-72. doi:

10.1073/pnas.0609584104

Auffhammer M, Ramanathan V, Vincent JR (2011) Climate change, the monsoon, and rice yield in India. Clim Change 111:411-424. doi: 10.1007/s10584-011-0208-4

Bates B, Kundzewicz ZW, Wu S, Palutikof J (2008) Climate Change and Water. Technical Paper of the Intergovernmental Panel on Climate Change. IPCC Secretariat, Geneva

Béguin A, Hales S, Rocklöv J, Åström C, Louis VR, Sauerborn R (2011) The opposing effects of climate change and socio-economic development on the global distribution of malaria. Glob Environ Chang 21:1209-1214. doi: 10.1016/j.gloenvcha.2011.06.001

Bierbaum RM, Fay M, Ross-Larson B [editor] (2009) World development report 2010: development and climate change. World Development Report. Washington, DC: World Bank Group.

http://documents.worldbank.org/curated/en/2010/01/11831971/world-development-report-2010-developmentclimate-change

Bollasina MA, Ming Y, Ramaswamy V (2011) Anthropogenic aerosols and the weakening of the South Asian summer monsoon. Science 334:502-5. doi: 10.1126/science.1204994

Brecht H, Dasgupta S, Laplante B, Murray S, Wheeler D (2012) Sea-Level Rise and Storm Surges: High Stakes for a Small Number of Developing Countries. J Environ Dev 21:120-138. doi: 10.1177/1070496511433601

Caron L-P, Jones CG (2008) Analysing present, past and future tropical cyclone activity as inferred from an ensemble of Coupled Global Climate Models. Tellus A 60:80-96. doi: 10.1111/j.1600-0870.2007.00291.x

Challinor AJ, Wheeler TR (2008) Crop yield reduction in the tropics under climate change: Processes and uncertainties. Agric For Meteorol 148:343-356. doi: 10.1016/j.agrformet.2007.09.015

Challinor AJ, Wheeler TR, Garforth C, Craufurd P, Kassam A (2007) Assessing the vulnerability of food crop systems in Africa to climate change. Clim Change 83:381-399. doi: 10.1007/s10584-007-9249-0

Chattopadhyay M, Abbs D (2012) On the variability of projected tropical cyclone genesis in GCM ensembles.

Tellus A 1:1-11.

Chou C, Tu J-Y, Tan P-H (2007) Asymmetry of tropical precipitation change under global warming. Geophys Res Lett 34:L17708. doi: 10.1029/2007GL030327

Collins M, AchutaRao K, Ashok K, Bhandari S, Mitra AK, Prakash S, Srivastava R, Turner A (2013) Observational challenges in evaluating climate models. Nat Clim Chang 3:940-941. doi: 10.1038/nclimate2012 
Coumou D, Robinson A (2013) Historic and future increase in the global land area affected by monthly heat extremes. Environ Res Lett 8:034018. doi: 10.1088/1748-9326/8/3/034018

Dai A (2012) Increasing drought under global warming in observations and models. Nat Clim Chang. doi: $10.1038 /$ nclimate 1633

De Fraiture C, Wichelns D (2010) Satisfying future water demands for agriculture. Agric Water Manag 97:502-511. doi: 10.1016/j.agwat.2009.08.008

De Stefano L, Duncan J, Dinar S, Stahl K, Strzepek KM, Wolf AT (2012) Climate change and the institutional resilience of international river basins. J Peace Res 49:193-209. doi: 10.1177/0022343311427416

Deka RL, Mahanta C, Pathak H, Nath KK, Das S (2012) Trends and fluctuations of rainfall regime in the Brahmaputra and Barak basins of Assam, India. Theor Appl Climatol. doi: 10.1007/s00704-012-0820-x

Diffenbaugh NS, Scherer M, Ashfaq M (2012) Response of snow-dependent hydrologic extremes to continued global warming. Nat Clim Chang 3:379-384. doi: 10.1038/nclimate1732

Döll P (2009) Vulnerability to the impact of climate change on renewable groundwater resources: a global-scale assessment. Environ Res Lett 4:035006. doi: 10.1088/1748-9326/4/3/035006

Douglas I (2009) Climate change, flooding and food security in south Asia. Food Secur 1:127-136. doi: 10.1007/s12571-009-0015-1

Ebi KL, Woodruff R, Hildebrand A, Corvalan C (2007) Climate Change-related Health Impacts in the Hindu KushHimalayas. Ecohealth 4:264-270. doi: 10.1007/s10393-007-0119-z

Elsner JB, Kossin JP, Jagger TH (2008) The increasing intensity of the strongest tropical cyclones. Nature 455:92-5. doi: 10.1038 /nature07234

Emanuel K, Sundararajan R, Williams J (2008) Hurricanes and Global Warming: Results from Downscaling IPCC AR4 Simulations. Bull Am Meteorol Soc 89:347-367. doi: 10.1175/BAMS-89-3-347

Endo H, Kitoh A, Ose T, Mizuta R, Kusunoki S (2012) Future changes and uncertainties in Asian precipitation simulated by multiphysics and multi-sea surface temperature ensemble experiments with high-resolution Meteorological Research Institute atmospheric general circulation models (MRI-AGCMs). J Geophys Res 117:D16118. doi: 10.1029/2012JD017874

ESCAP (2011) Statistical Yearbook for Asia and the Pacific 2011, Bangkok, Thailand: United Nations, Economic and Social Commission for Asia and the Pacific

Fung F, Lopez A, New M (2011) Water availability in $+2^{\circ} \mathrm{C}$ and $+4^{\circ} \mathrm{C}$ worlds. Philos Trans A Math Phys Eng Sci 369:99-116. doi: 10.1098/rsta.2010.0293

Gadgil S, Rupa Kumar K (2006) The Asian monsoon — agriculture and economy. In: Wang B (ed) The Asian Monsoon. Springer, Berlin, pp 651-683

Gain AK, Immerzeel WW, Sperna Weiland FC, Bierkens MFP (2011) Impact of climate change on the stream flow of the lower Brahmaputra: trends in high and low flows based on discharge-weighted ensemble modelling. Hydrol Earth Syst Sci 15:1537-1545. doi: 10.5194/hess-15-1537-2011

Gautam PK (2012) Climate Change and Conflict in South Asia. Strateg Anal 36:1:32-40. doi: http://dx.doi.org/10.1080/09700161.2012.628482 
Gautam R, Hsu NC, Lau KM, Kafatos M (2009) Aerosol and rainfall variability over the Indian monsoon region: Distributions, trends and coupling. Ann Geophys 27:3691-3703. doi: 10.5194/angeo-27-3691-2009

Gemenne F (2011) Why the numbers don't add up: A review of estimates and predictions of people displaced by environmental changes. Glob Environ Chang 21:S41-S49. doi: 10.1016/j.gloenvcha.2011.09.005

Gerten D, Heinke J, Hoff H, Biemans H, Fader M, Waha K (2011) Global Water Availability and Requirements for Future Food Production. J Hydrometeorol 12:885-899. doi: 10.1175/2011JHM1328.1

Ghosh S, Dutta S (2012) Impact of climate change on flood characteristics in Brahmaputra basin using a macroscale distributed hydrological model. J Earth Syst Sci 121:637-657. doi: 10.1007/s12040-012-0181-y

Giorgi F, Im E-S, Coppola E, Diffenbaugh NS, Gao XJ, Mariotti L, Shi Y (2011) Higher Hydroclimatic Intensity with Global Warming. J Clim 24:5309-5324. doi: 10.1175/2011JCLI3979.1

Gornall J, Betts R, Burke E, Clark R, Camp J, Willett K, Wiltshire A (2010) Implications of climate change for agricultural productivity in the early twenty-first century. Philos Trans R Soc Lond B Biol Sci 365:2973-89. doi: 10.1098/rstb.2010.0158

Goswami BN, Venugopal V, Sengupta D, Madhusoodanan MS, Xavier PK (2006) Increasing trend of extreme rain events over India in a warming environment. Science 314:1442-1445. doi: 10.1126/science.1132027

Green TR, Taniguchi M, Kooi H, Gurdak JJ, Allen DM, Hiscock KM, Treidel H, Aureli A (2011) Beneath the surface of global change: Impacts of climate change on groundwater. J Hydrol 405:532-560. doi:

10.1016/j.jhydrol.2011.05.002

Gualdi S, Scoccimarro E, Navarra A (2008) Changes in Tropical Cyclone Activity due to Global Warming: Results from a High-Resolution Coupled General Circulation Model. J Clim 21:5204-5228. doi: 10.1175/2008JCLI1921.1

Hajat S, Kosatky T, Kosatsky T (2010) Heat-related mortality: a review and exploration of heterogeneity. J Epidemiol Community Health 64:753-60. doi: 10.1136/jech.2009.087999

Hallegatte S, Bangalore M, Bonzanigo L, Fay M, Narloch U, Rozenberg J, Vogt-Schilb A (2014) Climate Change and Poverty - An Analytical Framework. Washington DC

Hertel TW, Burke MB, Lobell DB (2010) The poverty implications of climate-induced crop yield changes by 2030. Glob Environ Chang 20:577-585. doi: 10.1016/j.gloenvcha.2010.07.001

Hugo G (2011) Future demographic change and its interactions with migration and climate change. Glob Environ Chang 21:S21-S33. doi: 10.1016/j.gloenvcha.2011.09.008

Huq S, Ali SI, Rahman AA (1995) Sea-Level Rise and Bangladesh: A Preliminary Analysis. J Coast Res 44-53

Iglesias A, Erda L, Rosenzweig C (1996) Climate change in Asia: A review of the vulnerability and adaptation of crop production. Water, air soil Pollut 92:13-27

Immerzeel WW, van Beek LPH, Bierkens MFP (2010) Climate change will affect the Asian water towers. Science 328:1382-5. doi: 10.1126/science.1183188

Jacoby H, Mariano R, Skoufias E (2011) Distributional Implications of Climate Change in India. Washington DC 
Jourdain NC, Gupta AS, Taschetto AS, Ummenhofer CC, Moise AF, Ashok K (2013) The Indo-Australian monsoon and its relationship to ENSO and IOD in reanalysis data and the CMIP3/CMIP5 simulations. Clim Dyn 41:30733102. doi: 10.1007/s00382-013-1676-1

Kalra N, Chakraborty D, Sharma A, Rai HK, Jolly M, Chander S, Kumar PR, Bhadraray S, Barman D, Mittal RB, Lal M, Sehgal M (2008) Effect of increasing temperature on yield of some winter crops in northwest India. Curr Sci 94:82-88

Khan AE, Ireson A, Kovats S, Mojumder SK, Khusru A, Rahman A, Vineis P (2011) Drinking water salinity and maternal health in coastal Bangladesh: Implications of climate change. Environ Health Perspect 119:1328-1332. doi: 10.1289/ehp.1002804

Khan AE, Xun WW, Ahsan H, Vineis P (2011) Climate Change, Sea-Level Rise, \& Health Impacts in Bangladesh. Environ Sci Policy Sustain Dev 53:37-41. doi: 10.1080/00139157.2011.604008

Kim D-W, Byun H-R (2009) Future pattern of Asian drought under global warming scenario. Theor Appl Climatol 98:137-150. doi: 10.1007/s00704-008-0100-y

Kim J-H, Brown SJ, McDonald RE (2011) Future changes in tropical cyclone genesis in fully dynamic ocean- and mixed layer ocean-coupled climate models: a low-resolution model study. Clim Dyn 37:737-758. doi:

10.1007/s00382-010-0855-6

Knutson TR, McBride JL, Chan J, Emanuel K, Holland G, Landsea C, Held I, Kossin JP, Srivastava AK, Sugi M (2010) Tropical cyclones and climate change. Nat Geosci 3:157-163. doi: 10.1038/ngeo779

Kripalani RH, Oh JH, Kulkarni A, Sabade SS, Chaudhari HS (2007) South Asian summer monsoon precipitation variability: Coupled climate model simulations and projections under IPCC AR4. Theor Appl Climatol 90:133-159. doi: 10.1007/s00704-006-0282-0

Krishnan R, Sabin TP, Ayantika DC, Kitoh A, Sugi M, Murakami H, Turner AG, Slingo JM, Rajendran K (2012) Will the South Asian monsoon overturning circulation stabilize any further? Clim Dyn 40:187-211. doi: 10.1007/s00382-012-1317-0

Kumar KK, Kamala K, Rajagopalan B, Hoerling MP, Eischeid JK, Patwardhan SK, Srinivasan G, Goswami BN, Nemani R (2010) The once and future pulse of Indian monsoonal climate. Clim Dyn 36:2159-2170. doi: 10.1007/s00382-010-0974-0

Ladha JK, Dawe D, Pathak H, Padre AT, Yadav RL, Singh B, Singh Y, Singh Y, Singh P, Kundu AL, Sakal R, Ram N, Regmi AP, Gami SK, Bhandari AL, Amin R, Yadav CR, Bhattarai EM, Das S, Aggarwal HP, Gupta RK, Hobbs PR (2003) How extensive are yield declines in long-term rice-wheat experiments in Asia? F Crop Res 81:159-180. doi: $10.1016 / \mathrm{S} 0378-4290(02) 00219-8$

Lal M (2011) Implications of climate change in sustained agricultural productivity in South Asia. Reg Environ Chang 11:79-94. doi: 10.1007/s10113-010-0166-9

Lin M, Huybers P (2012) Reckoning wheat yield trends. Environ Res Lett 7:024016. doi: 10.1088/1748$9326 / 7 / 2 / 024016$

Lloyd SJ, Kovats RS, Chalabi Z (2011) Children's Health Climate Change, Crop Yields, and Undernutrition: Development of a Model to Quantify the Impact of Climate Scenarios on Child Undernutrition. 1817-1824 
Lobell DB, Schlenker W, Costa-Roberts J (2011) Climate trends and global crop production since 1980. Science 333:616-20. doi: 10.1126/science.1204531

Lobell DB, Sibley AS, Ivan Ortiz-Monasterio J, Ortiz-Monasterio JI (2012) Extreme heat effects on wheat senescence in India. Nat Clim Chang 2:186-189. doi: 10.1038/nclimate1356

Mall RK, Singh R, Gupta A, Srinivasan G, Rathore LS (2006) Impact of Climate Change on Indian Agriculture: A Review. Clim Change 78:445-478. doi: 10.1007/s10584-005-9042-x

May W (2010) The sensitivity of the Indian summer monsoon to a global warming of $2^{\circ} \mathrm{C}$ with respect to preindustrial times. Clim Dyn 37:1843-1868. doi: 10.1007/s00382-010-0942-8

Mearns R, Norton A (2009) Social dimensions of climate change: equity and vulnerability in a warming world. New frontiers of social policy. Washington, DC: World Bank.

Menon A, Levermann A, Schewe J, Lehmann J, Frieler K (2013a) Consistent increase in Indian monsoon rainfall and its variability across CMIP-5 models. Earth Syst Dyn 4:287-300. doi: 10.5194/esd-4-287-2013

Menon A, Levermann A, Schewe J (2013b) Enhanced future variability during India's rainy season. Geophys Res Lett 40:3242-3247. doi: 10.1002/grl.50583

Ministry of Environment and Forests, Government of India (2012) India Second National Communication to the United Nations Framework Convention on Climate Change. New Delhi

Mirza MMQ (2010) Climate change, flooding in South Asia and implications. Reg Environ Chang 11:95-107. doi: 10.1007/s10113-010-0184-7

Müller C, Bondeau A, Popp A, Waha K (2010) Development and Climate Change Background Note - Climate Change Impacts on Agricultural Yield. Potsdam, Washington DC

Murakami H, Sugi M, Kitoh A (2013) Future changes in tropical cyclone activity in the North Indian Ocean projected by high-resolution MRI-AGCMs. Clim Dyn 40:1949-1968. doi: 10.1007/s00382-012-1407-z

Murakami H, Wang Y, Yoshimura H, Mizuta R, Sugi M, Shindo E, Adachi Y, Yukimoto S, Hosaka M, Kusunoki S, Ose T, Kitoh A (2012) Future Changes in Tropical Cyclone Activity Projected by the New High-Resolution MRIAGCM*. J Clim 25:3237-3260. doi: 10.1175/JCLI-D-11-00415.1

NASA (2007) Powerful Tropical Cyclone Sidr Makes Landfall in Bangladesh. http://www.nasausa.de/mission_pages/hurricanes/archives/2007/h2007_sidr.html. Accessed 26 Jan 2015

Nelson GC, Rosegrant MW, Koo J, Robertson R, Sulser T, Zhu T, Ringler C, Msangi S, Palazzo A, Batka M, Magalhaes M, Valmonte-Santos R, Ewing M, Lee D (2010) The Costs of Agricultural Adaptation to Climate Change. Washington DC

Pandey K (2010) Costs of Adapting to Climate Change for Human Health in Developing Countries. Washington DC Parry M (2010) Copenhagen number crunch. Nat Reports Clim Chang 4:18-19. doi: 10.1038/climate.2010.01

Pathak H, Ladha JK, Aggarwal PK, Peng S, Das S, Singh Y, Singh B, Kamra SK, Mishra B, Sastri ASRAS, Aggarwal HP, Das DK, Gupta RK (2003) Trends of climatic potential and on-farm yields of rice and wheat in the Indo-Gangetic Plains. F Crop Res 80:223-234. doi: 10.1016/S0378-4290(02)00194-6 
Perrette M, Landerer F, Riva R, Frieler K, Meinshausen M (2013) A scaling approach to project regional sea level rise and its uncertainties. Earth Syst Dyn 4:11-29. doi: 10.5194/esd-4-11-2013

Rockström J, Falkenmark M, Karlberg L, Hoff H, Rost S, Gerten D (2009) Future water availability for global food production: The potential of green water for increasing resilience to global change. Water Resour Res 45:1-16. doi: 10.1029/2007WR006767

Sabade SS, Kulkarni A, Kripalani RH (2010) Projected changes in South Asian summer monsoon by multi-model global warming experiments. Theor Appl Climatol 103:543-565. doi: 10.1007/s00704-010-0296-5

Sadoff BC, Muller M (2009) Water Management, Water Security and Climate Change Adaptation: Early Impacts and Essential Responses. Stockholm

Schewe J, Levermann A (2012) A statistically predictive model for future monsoon failure in India. Environ Res Lett 7:044023. doi: 10.1088/1748-9326/7/4/044023

Sillmann J, Kharin VV, Zwiers FW, Zhang X, Bronaugh D (2013) Climate extremes indices in the CMIP5 multimodel ensemble: Part 2. Future climate projections. J Geophys Res Atmos 118:2473-2493. doi:

10.1002/jgrd.50188

Singh N, Sontakke NA (2002) On climatic fluctuations and environmental changes of the indo-gangetic plains, India. Clim Change 52:287-313

Sperber KR, Annamalai H, Kang IS, Kitoh A, Moise A, Turner A, Wang B, Zhou T (2013) The Asian summer monsoon: An intercomparison of CMIP5 vs. CMIP3 simulations of the late 20th century. Clim Dyn 41:2711-2744. doi: $10.1007 / \mathrm{s} 00382-012-1607-6$

Srivastava A, Naresh Kumar S, Aggarwal PK (2010) Assessment on vulnerability of sorghum to climate change in India. Agric Ecosyst Environ 138:160-169. doi: 10.1016/j.agee.2010.04.012

Syvitski JPM, Kettner AJ, Overeem I, Hutton EWH, Hannon MT, Brakenridge GR, Day J, Vörösmarty C, Saito Y, Giosan L, Nicholls RJ (2009) Sinking deltas due to human activities. Nat Geosci 2:681-686. doi: 10.1038/ngeo629

Takahashi K, Honda Y, Emori S (2007) Assessing Mortality Risk from Heat Stress due to Global Warming. J Risk Res 10:339-354. doi: 10.1080/13669870701217375

Taylor IH, Burke E, McColl L, Falloon P, Harris GR, McNeall D (2012) Contributions to uncertainty in projections of future drought under climate change scenarios. Hydrol Earth Syst Sci Discuss 9:12613-12653. doi:

10.5194/hessd-9-12613-2012

Tory KJ, Chand SS, McBride JL, Ye H, Dare RA(2013) Projected Changes in Late-Twenty-First-Century Tropical Cyclone Frequency in 13 Coupled Climate Models from Phase 5 of the Coupled Model Intercomparison Project. J Clim 26:9946-9959. doi: 10.1175/JCLI-D-13-00010.1

Turner AG, Annamalai H (2012) Climate change and the South Asian summer monsoon. Nat Clim Chang. doi: $10.1038 /$ nclimate 1495

UNISDR (2011) Global Assessment Report on Disaster Risk Reduction. Geneva, Switzerland: United Nations International Strategy for Disaster Reduction

Uprety K, Salman SMA (2011) Legal aspects of sharing and management of transboundary waters in South Asia: preventing conflicts and promoting cooperation. Hydrol Sci J 56:641-661. doi: 10.1080/02626667.2011.576252 
Van Vliet MTH, Franssen WHP, Yearsley JR, Ludwig F, Haddeland I, Lettenmaier DP, Kabat P (2013) Global river discharge and water temperature under climate change. Glob Environ Chang. doi: 10.1016/j.gloenvcha.2012.11.002

Vörösmarty CJ, McIntyre PB, Gessner MO, Dudgeon D, Prusevich A, Green P, Glidden S, Bunn SE, Sullivan CA, Liermann CR, Davies PM (2010) Global threats to human water security and river biodiversity. Nature 467:555-61. doi: 10.1038/nature09440

Wang B, Liu J, Kim H-J, Webster PJ, Yim S-Y (2011) Recent change of the global monsoon precipitation (19792008). Clim Dyn 39:1123-1135. doi: 10.1007/s00382-011-1266-Z

Warszawski L, Frieler K, Huber V, Piontek F, Serdeczny O, Schewe J (2014) The Inter-Sectoral Impact Model Intercomparison Project (ISI-MIP): project framework. Proc Natl Acad Sci U S A 111:3228-32. doi:

$10.1073 /$ pnas. 1312330110

Wassmann R, Jagadish SVK, Heuer S (2009a) Climate change affecting rice production: the physiological and agronomic basis for possible adaptation strategies. Adv Agron 101:59-122. doi: 10.1016/S0065-2113(08)00802-X

Wassmann R, Jagadish SVK, Sumfleth K, Pathak H, Howell G, Ismail A, Serraj R, Redona E, Singh RK, Heuer S (2009b) Chapter 3 Regional Vulnerability of Climate Change Impacts on Asian Rice Production and Scope for Adaptation. Adv. Agron. 102:91-133

Webster PJ, Holland GJ, Curry JA, Chang H-R (2005) Changes in tropical cyclone number, duration, and intensity in a warming environment. Science 309:1844-6. doi: 10.1126/science.1116448

Webster PJ, Magaña VO, Palmer TN, Shukla J, Tomas RA, Yanai M, Yasunari T (1998) Monsoons: Processes, predictability, and the prospects for prediction. J Geophys Res 103:14451. doi: 10.1029/97JC02719

Webster PJ, Toma VE, Kim HM (2011) Were the 2010 Pakistan floods predictable? Geophys Res Lett. doi: 10.1029/2010GL046346

World Bank (2010) Bangladesh - Economic of adaptation to climate change. Washington, DC: World Bank.

World Bank (2012) Turn Down the Heat: Why a $4^{\circ} \mathrm{C}$ Warmer World Must be Avoided. A report for the World Bank by the Potsdam Institute for Climate Impact Research and Climate Analytics. Washington, DC: World Bank.

World Bank (2013a) Data: Indicators. http://data.worldbank.org/indicator. Accessed 26 Jan 2015

World Bank (2013b) Turn Down the Heat: Climate Extremes, Regional Impacts, and the Case for Resilience. A report for the World Bank by the Potsdam Institute for Climate Impact Research and Climate Analytics.

Washington, DC: World Bank.

World Bank (2014) Turn Down the Heat: Confronting the New Climate Normal. Washington, DC: World Bank.

Yu WH, Alam M, Hassan A, Khan AS, Ruane AC, Rosenzweig C, Major DC, Thurlow J (2010) Climate Change Risks and Food Security in Bangladesh. Washington DC 